\title{
PENGARUH KEMANDIRIAN KEUANGAN DAERAH TERHADAP PERTUMBUHAN EKONOMI KABUPATEN/KOTA PROVINSI BANTEN
}

\author{
Stannia Cahaya Suci dan Alla Asmara ${ }^{2}$ \\ ${ }^{1,2}$ Departemen Ilmu Ekonomi, Fakultas Ekonomi dan Manajemen \\ Institut Pertanian Bogor
}

Artikel diterima Februari 2013

Artikel disetujui untuk dipublikasikan Juli 2014

\begin{abstract}
Fiscal decentralization aims to improve regional finance independency and reduce the fiscal dependency of central government. However, in practice, there are many areas that still rely on the assistance central finance for their regional development. This research aims to discuss the development of regional finance independency and analyze the influence of regional finance independency on economic growth in Banten Province. This research uses descriptive method and panel data on 6 (six) regencies and cities in Banten Province at 2001-2011. The results showed the significantly positive effect of regional finance independency on economic growth and significantly negative effect of balance fund's ratio on economic growth.
\end{abstract}

Key words: local revenue, economic growth, panel data

\begin{abstract}
ABSTRAK
Desentralisasi fiskal bertujuan untuk meningkatkan kemandirian keuangan daerah dan mengurangi ketergantungan fiskal terhadap pemerintah pusat, namun pada pelaksanaannya masih banyak daerah yang bergantung pada bantuan dana pusat untuk pembangunan daerah. Penelitian ini akan menganalisis perkembangan kemandirian keuangan daerah di Provinsi Banten dan pengaruhnya terhadap pertumbuhan ekonomi di Provinsi Banten. Penelitian ini menggunakan metode deskriptif dan panel data pada 6 (enam) kabupaten dan kota di Provinsi Banten tahun 2001-2011. Hasil penelitian menunjukkan bahwa kemandirian keuangan daerah berpengaruh positif secara signifikan terhadap pertumbuhan ekonomi sedangkan rasio Dana Perimbangan berpengaruh negatif secara signifikan terhadap pertumbuhan ekonomi.
\end{abstract}

Kata Kunci: pendapatan asli daerah, pertumbuhan ekonomi, panel data

\section{PENDAHULUAN}

Salah satu aspek penting
pelaksanaan kewenangan
daerah adalah mengetahui tingkat
kemandirian daerah dalam membiayai
kegiatan penyelenggaraan pemerintahan
dan pembangunan melalui peningkatan
potensi penerimaan daerah (Enceng et
al., 2012). Semakin tinggi tingkat
kemandirian keuangan daerah,
menggambarkan bahwa pemerintah

daerah telah mampu meningkatkan kemampuan keuangan yang berasal dari daerah lokal serta mengurangi ketergantungan terhadap bantuan dana pemerintah pusat. Kemandirian keuangan daerah dapat dilihat dari penerimaan Pendapatan Asli Daerah (PAD) terhadap total pendapatan daerah. Penerimaan PAD terhadap total pendapatan daerah disajikan pada Tabel 1. Berdasarkan Tabel 1, komposisi realisasi pendapatan daerah Provinsi 
Banten selama kurun waktu tahun 20012011 terdiri dari $67,71 \%$ PAD, 30,99\% Dana Perimbangan, $0,72 \%$ Lain-lain Pendapatan Daerah yang Sah dan 0,58\% Bagian Sisa Lebih Anggaran Tahun Lalu. Penerimaan pendapatan daerah yang berasal dari PAD lebih besar dari pendapatan yang berasal dari Dana Perimbangan menunjukkan kemampuan Provinsi Banten semakin tinggi untuk membiayai kemampuan keuangannya sendiri dan menunjukkan kinerja keuangan daerah yang positif.

Tabel 1. Komposisi realisasi pendapatan daerah Provinsi Banten tahun 2001-2011

\begin{tabular}{lcc}
\hline \multicolumn{1}{c}{ Uraian } & $\begin{array}{c}\text { Realisasi } \\
\text { (Juta Rupiah) }\end{array}$ & $\begin{array}{c}\text { Komposisi } \\
\text { Pendapatan Daerah } \\
(\%)\end{array}$ \\
\hline $\begin{array}{l}\text { Bagian Sisa Lebih } \\
\text { Anggaran Tahun Lalu }\end{array}$ & 114.750 & 0,58 \\
$\begin{array}{l}\text { Lain-lain Pendapatan } \\
\text { Yang Sah }\end{array}$ & 141.271 & 0,72 \\
$\begin{array}{l}\text { Dana Perimbangan } \\
\text { Pendapatan Asli Daerah }\end{array}$ & 6.115 .427 & 30,99 \\
$\quad$ Jumlah & 13.358 .962 & 67,71 \\
\hline
\end{tabular}

Sumber: DPPKD Banten, 2012

Realisasi pendapatan daerah kabupaten dan kota di Provinsi Banten tahun 2001-2011 dapat dilihat pada Gambar 1. Berdasarkan Gambar 1, seluruh kabupaten dan kota memiliki penerimaan pendapatan Dana Perimbangan lebih besar daripada PAD. Kabupaten Pandeglang memiliki penerimaan Dana Perimbangan tertinggi dibandingkan kabupaten dan kota lainnya yaitu sebesar $88.43 \%$. Provinsi Banten memiliki kemampuan keuangan daerah yang tinggi dan berhasil

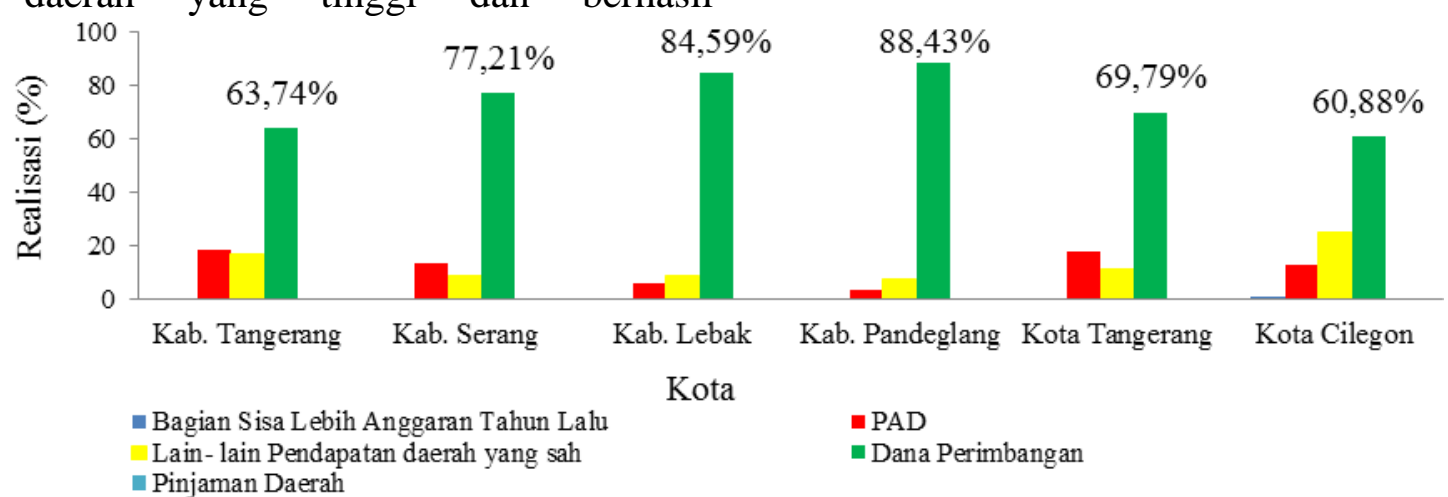

Sumber: DPPKD Banten, 2013

Gambar 1. Realisasi pendapatan daerah Provinsi Banten tahun 2001-2011

Pertumbuhan ekonomi yang tinggi sering disebutkan sebagai tujuan dari pelaksanaan otonomi daerah dan

melaksanakan kebijakan daerah untuk meningkatkan PAD-nya, namun realisasi pendapatan dana daerah masing-masing kabupaten dan kota menunjukkan ketergantungan terhadap dana pemerintah pusat memiliki proporsi yang besar. Perbedaan proporsi pendapatan daerah masing-masing kabupaten dan kota salah satunya dapat dipengaruhi oleh kemampuan daerah dalam mengembangkan potensi daerah masingmasing. desentralisasi fiskal. Pertumbuhan ekonomi Provinsi Banten dilihat pada 
Tabel 2 yang menunjukkan Provinsi Banten masih memiliki kabupaten yang memiliki pertumbuhan ekonomi yang rendah, yaitu Kabupaten Pandeglang yang memiliki laju pertumbuhan ekonomi hanya sebesar $5.40 \%$ pada tahun 2011 yang menurun dari nilai 7.16\% pada tahun 2010. Jika suatu daerah memiliki kemandirian keuangan daerah yang tinggi, maka diharapkan pertumbuhan ekonomi daerah tersebut akan tinggi. Oleh karena pertumbuhan ekonomi di suatu wilayah provinsi merupakan komposit dari pertumbuhan ekonomi kabupaten serta kota, maka perlu dicermati tingkat kemandirian kabupaten dan kota serta pemerintah provinsi yang bersangkutan. Oleh karena itu, perlu dilakukan penelitian yang mengkaji hubungan antara kemandirian keuangan daerah yang tercermin dalam kinerja fiskal daerah, pertumbuhan ekonomi.

Tabel 2. Laju pertumbuhan PDRB atas dasar harga konstan 2000

\begin{tabular}{lcc}
\hline Kabupaten/Kota & $\begin{array}{c}\text { Laju Pertumbuhan PDRB } \\
\text { Tahun 2010 }(\%)\end{array}$ & $\begin{array}{c}\text { Laju Pertumbuhan PDRB } \\
\text { Tahun 2011(\%) }\end{array}$ \\
\hline Kabupaten Pandeglang & 7,16 & 5,40 \\
Kabupaten Lebak & 6.59 & 6,44 \\
Kabupaten Tangerang & 6.71 & 7,35 \\
Kabupaten Serang & 4.15 & 5,67 \\
Kota Tangerang & 6.68 & 7,03 \\
Kota Cilegon & 5.32 & 6,53 \\
Provinsi Banten & 6,08 & 6,43 \\
\hline
\end{tabular}

Sumber: BPS Banten, 2013

Berdasarkan uraian diatas, maka tujuan penelitian ini adalah menganalisis perkembangan kemandirian keuangan daerah kabupaten dan kota di Provinsi Banten tahun 2001-2011 serta menganalisis pengaruh kemandirian keuangan daerah tersebut terhadap pertumbuhan ekonomi kabupaten dan kota Provinsi Banten. Penelitian ini diharapkan dapat memberikan masukan

\section{MATERI DAN METODE}

\section{Otonomi Daerah dan Desentralisasi Fiskal}

Otonomi atau autonomy berasal dari bahasa Yunani, auto yang berarti sendiri dan nomous yang berarti hukum dan peraturan. Kebijakan otonomi dan kewenangan desentralisasi sangat penting untuk menjamin proses integrasi nasional terpelihara dengan baik. Hal ini karena untuk mengelola keuangan daerah dan Anggaran Pendapatan Belanja Daerah (APBD), memberikan pengetahuan umum yang dapat diambil manfaatnya, khususnya pengentahuan mengenai keuangan daerah, perekonomian dan kemiskinan Provinsi Banten dan menjadi salah satu sumber referensi yang baik bagi kegiatan penulisan dan penelitian selanjutnya.

dalam sistem yang berlaku sebelumnya, ketidakadilan struktural dalam hubungan antara pusat dan daerah sangat jelas terlihat. Kebijakan otonomi dan kewenangan desentralisasi tidak hanya menyangkut pengalihan kewenangan dari atas ke bawah, tetapi juga perlu diwujudkan atas dasar prakarsa dari bawah untuk mendorong tumbuhnya kemandirian pemerintahan daerah sebagai 
faktor yang menentukan keberhasilan kebijakan otonomi daerah.

Menurut Undang-Undang Nomor 32 Tahun 2004 tentang Pemerintahan Daerah Pasal 1 ayat 5, Otonomi daerah adalah hak, wewenang, dan kewajiban daerah otonom untuk mengatur dan mengurusi sendiri urusan pemerintahan dan kepentingan masyarakat setempat sesuai dengan peraturan perundangundangan. Otonomi daerah ditegaskan dengan lahirnya Undang-Undang Nomor 22 Tahun 1999 kemudian diperbaharui dengan Undang-Undang Nomor 32 Tahun 2004 tentang Pemerintahan Daerah.

Otonomi daerah dilaksanakan dengan azas desentralisasi, dekosentrasi dan tugas pembantuan. Desentralisasi adalah penyerahan wewenang pemerintahan oleh pemerintah daerah kepada daerah otonom untuk mengatur dan mengurus urusan pemerintahan dalam system Negara Kesatuan Republik Indonesia. Dekosentrasi adalah pelimpahan wewenang pemerintahan oleh pemerintah kepada gubernur sebagai wakil pemerintah dan/atau kepada instansi vertikal di wilayah tertentu. Tugas pembantuan adalah penugasan dari pemerintah kepada daerah dan/atau desa dari pemerintah provinsi kepada kabupaten/kota dan/atau desa serta pemerintah kabupaten kota kepada desa untuk melaksanakan tugas tertentu.

Pemerintah daerah diberi wewenang dan keleluasaan di seluruh bidang pemerintahan, kecuali dalam bidang politik luar negeri, pertahanan keamanan, peradilan, moneter dan fiskal, agama, perencanaan nasional dan pengendalian pembangunan nasional secara makro, dana perimbangan keuangan, sistem administrasi dan perekonomian negara, pembinaan dan pemberdayaan sumber daya manusia, pendayagunaan sumber daya alam serta teknologi tinggi yang strategis, konservasi dan standarisasi nasional.

\section{Sumber-sumber Penerimaan Daerah}

Pendapatan Asli Daerah. Peningkatan kemandirian daerah sangat erat kaitannya dengan kemampuan daerah dalam mengelola Pendapatan Asli Daerah (PAD). Semakin tinggi kemampuan daerah dalam menghasilkan PAD, maka semakin besar pula kemampuan daerah untuk menggunakan PAD tersebut sesuai aspirasi, kebutuhan dan prioritas pembangunan daerah. PAD merupakan sumber penerimaan daerah yang didapat dan digunakan sesuai dengan potensi daerah yang dimiliki. PAD bertujuan memberikan kewenangan kepada pemerintah daerah untuk mendanai pelaksanaan otonomi daerah sesuai dengan potensi daerah sebagai perwujudan desentralisasi.

Sumber-sumber PAD terdiri dari: (1) Pajak Daerah yaitu kontribusi wajib oleh pribadi atau badan kepada daerah tanpa imbalan secara langsung yang digunakan untuk keperluan daerah bagi kemakmuran rakyat. Pajak terdiri dari pajak provinsi dan kabupaten dan kota, (2) Restribusi Daerah yang merupakan pungutan yang dilakukan pemerintah daerah kepada wajib restribusi atas pemanfaatan suatu jasa tertentu yang disediakan pemerintah, dalam hal ini terdapat imbalan langsung yang dapat dinikmati pembayar restribusi. Berbeda dengan pajak daerah yang bersifat tertutup, dalam restribusi ini, pemerintah daerah diberi peluang untuk menambah jenisnya namun harus sesuai dengan undang-undang yang berlaku.

Restribusi daerah terdiri atas 3 jenis, yaitu: (a) Restribusi Jasa Umum merupakan restribusi yang disediakan oleh pemerintah daerah dengan tujuan kepentingan dan kemanfaatan umum serta dapat dinikmati oleh pribadi atau badan, (b) Restribusi Jasa Usaha merupakan restribusi jasa yang disediakan oleh pemerintah daerah yang menganut prinsip komersial karena dapat disediakan oleh sektor swasta dan 
bertujuan untuk mendapatkan keuntungan yang layak. (c) Restribusi Perizinan Tertentu merupakan restribusi atas kegiatan pemerintah daerah tertentu yang meliputi pemberian izin kepada pribadi atau badan yang bertujuan untuk pengaturan dan pengawasan pemberian izin tersebut guna melindungi kepentingan umum dan menjaga kelestarian lingkungan. (3) Hasil Pengelolaan Kekayaan Daerah yang Dipisahkan dan Lain-lain PAD yang Sah

Dana Perimbangan. Dana Perimbangan adalah dana yang bersumber dari pendapatan Anggaran Pendapatan dan Belanja Negara (APBN) yang dialokasikan kepada daerah untuk mendanai kebutuhan daerah dalam rangka pelaksanaan desentralisasi yang bertujuan mengurangi kesenjangan fiskal antara pemerintah dan pemerintahan daerah dan antar pemerintahan daerah. Dana Perimbangan diharapkan dapat meningkatkan kapasitas fiskal daerah dan mengurangi kesenjangan fiskal. Dana Perimbangan bersifat subtitusi terhadap PAD. Penerimaan Dana Perimbangan bervariasi bergantung pada penerimaan PAD daerah tersebut. Penerimaan Dana Perimbangan umumnya naik jika daerah tersebut menerima Dana Bagi Hasil dan PAD yang rendah. Penerimaan Dana Perimbangan dapat turun, umumnya terjadi pada daerah yang mengalami kenaikan PAD dan kapasitas fiskal yang berarti.

Penerimaan Dana Perimbangan yang berasal dari Dana Alokasi Umum dan Dana Alokasi khusus dapat mencapai angka 0 (nol), bukan karena tidak dihitung melaikan hasil perhitungan menunjukkan nilai minus atau nol, umumnya terjadi pada daerah dengan kapasitas fiskal yang tinggi karena memiliki penerimaan PAD yang sangat tinggi. (Direktorat Jenderal Perimbangan Keuangan, 2013).
Lain-lain pendapatan. Lain-lain pendapatan terdiri atas pendapatan hibah dan pendapatan Dana Darurat. Pendapatan hibah merupakan bantuan yang tidak mengikat. Hibah kepada daerah yang bersumber dari luar negeri dilakukan melalui pemerintah. Dana Darurat dialokasikan oleh pemerintah dimana dananya berasal dari APBN untuk keperluan mendesak yang diakibatkan oleh bencana nasional atau peristiwa luar biasa yang tidak dapat ditanggulangi oleh daerah dengan menggunakan sumber APBD.

\section{Kemandirian Keuangan Daerah dan Derajat Desentralisasi Fiskal}

Kemampuan daerah dalam menjalani otonomi daerah dapat diukur dengan kinerja keuangan daerah yang dapat dilihat dari kemandirian daerah dan derajat desentralisasi fiskal. Kemandirian keuangan daerah merupakan gambaran pemerintah daerah dalam hal ketergantungan daerah terhadap sumber dana pemerintah pusat dan propinsi. Semakin tinggi kemandirian keuangan daerah, maka ketergantungan daerah terhadap bantuan pemerintah dan propinsi semakin rendah.

Kemandirian keuangan daerah juga menggambarkan tingkat partisipasi masyarakat dalam pembangunan daerah, dimana semakin tinggi kemandirian keuangan daerah menggambarkan semakin tingginya pastisipasi masyarakat dalam membayar pajak dan restribusi daerah. Pajak dan restribusi daerah merupakan komponen dari PAD. Kemandirian keuangan daerah dapat ditunjukkan dari perbandingan PAD dengan pendapatan yang berasal dari pemerintah pusat.

Derajat desentralisasi fiskal yang tinggi mengindikasikan pemerintah daerah telah mampu meningkatkan PAD dibandingkan pendapatan lain pada pendapatan daerah. Jika rasio PAD tinggi 
akan mengurangi ketergantungan pemerintah daerah pada penggunaan dana

\section{Pertumbuhan Ekonomi dan Desentralisasi Fiskal}

Teori Ekonomi Klasik yang dikemukakan Adam Smith menyatakan pertumbuhan ekonomi bergantung pada pertumbuhan penduduk dengan kata lain pertambahan penduduk akan meningkatkan output produksi. Teori Klasik ini berkembang menjadi Teori Neoklasik dikemukakan oleh HarrodDomar dan Robert Solow. Model Harrod-Domar mengemukakan bahwa pertumbuhan ekonomi sangat dipengaruhi oleh pembentukan modal oleh karena itu modal harus dipakai secara efektif, sedangkan Solow mengembangkan model Harrod-Domar ini menyatakan bahwa faktor tenaga kerja dan teknologi masuk ke dalam model pertumbuhan, oleh karena itu pertumbuhan ekonomi merupakan rangkaian kegiatan yang bersumber pada manusia, akumulasi modal dan pemakaian teknologi modern (Mankiw, 2007)

Pertumbuhan ekonomi adalah terjadinya pertambahan atau perubahan pendapatan nasional (produksi nasional) dalam satu tahun tertentu, tanpa memperhatikan pertumbuhan penduduk dan aspek lainnya. Pertumbuhan ekonomi dalam pengertian makro adalah penambahan nilai Produk Domestik Bruto riil (PDB) atau peningkatan pendapatan nasional. Menurut Mankiw (2007), PDB sering dianggap sebagai ukuran terbaik dari kinerja perekonomian yang tujuannya adalah meringkas aktivitas ekonomi dalam suatu nilai uang tertentu selama periode waktu tertentu. Pertumbuhan ekonomi yang dicapai dari penggunaan banyak tenaga tenaga kerja, tidak menghasilkan pertumbuhan pendapatan per kapita, namun jika pertumbuhan ekonomi dicapai dari dari daerah pusat.

penggunaan sumberdaya yang lebih produktif, hal tersebut dapat menghasilkan pendapatan per kapita yang lebih tinggi dan meningkatkan standar hidup rata-rata masyarakat. Badan Pusat Statistik menggunakan pendekatan PDB dan Pendapatan Domestik Regional Bruto (PDRB) untuk menggambarkan produksi barang dan jasa yang dihasilkan oleh suatu daerah dicerminkan untuk mencerminkan pertumbuhan ekonomi.

Menurut Badan Pusat Statistik (2013), PDRB menyatakan pendapatan total dan pengeluaran total daerah atas output barang dan jasa suatu daerah. PDRB dapat dihitung dengan dua cara, yaitu atas dasar harga berlaku dan atas dasar harga konstan. PDRB atas dasar harga berlaku menggunakan harga pada tahun berjalan, pada saat menilai produksi, biaya antara dan komponen nilai tambah sedangkan PDRB atas dasar harga konstan menggunakan harga barang dan jasa pada tahun dasar, saat ini yang digunakan adalah harga konstan 2000.

Desentralisasi fiskal merupakan salah satu pilar dalam memelihara kestabilan kondisi ekonomi nasional, karena dengan adanya transfer dana ke daerah akan mendorong aktivitas perekonomian masyarakat di daerah. Hubungan antara desentralisasi fiskal dan pertumbuhan ekonomi telah banyak dianalisis oleh para ekonom. Samimi et al. (2010) menyatakan bahwa penelitian dilakukan karena pertumbuhan ekonomi dipandang sebagai tujuan dari desentralisasi fiskal dan efisiensi dalam alokasi sumberdaya di sektor publik serta sebagai bagian dari tujuan pemerintah secara eksplisit untuk mengambil kebijakan-kebijakan yang mengarah pada peningkatan pendapatan perkapita.

Menurut Davoodi dan Zou (1998), desentralisasi fiskal adalah bagian dari 
reformasi peningkatan efisiensi di sektor publik dan peningkatan kompetisi antara pemerintah daerah dalam pemenuhan kebutuhan publik yang dalam menstimulasi pertumbuhan ekonomi.

Menurut Tiebout (1961) argumen ekonomi dasar yang mendukung desentralisasi fiskal berdasarkan dua asumsi yang saling melengkapi yaitu desentralisasi akan meningkatkan efisiensi ekonomi karena pemerintah daerah diposisikan lebih baik daripada pemerintah pusat dalam penyediaan pelayanan publik sebagai hasil keuntungan informasi dan mobilitas penduduk serta persaingan antara pemerintah daerah dalam penyediaan pelayanan publik akan menjamin kecocokan preferensi masyarakat dan pemerintah daerah.

Oates (1999) menyatakan bahwa sistem desentralisasi fiskal dimana pemerintah daerah memainkan peran yang lebih penting daripada pemerintah pusat dalam penyediaan pelayanan publik akan mendorong pertumbuhan ekonomi yang lebih cepat.

\section{Metode Penelitian}

Pendekatan standar untuk mengukur alokasi kewenangan adalah menggunakan pengukuran akuntansi seperti pendapatan atau pengeluaran (Akai dan Sakata, 2002). Berdasarkan hasil-hasil penelitian sebelumnya, menyimpulkan bahwa tidak terdapat pengukuran yang pasti mengenai derajat desentralisasi ataupun kemandirian keuangan daerah. Variabel yang digunakan dapat berubah-ubah sesuai dengan karakteristik keuangan daerah tempat penelitian dilakukan.

Penelitian ini, sebagai pengukuran kemandirian keuangan daerah digunakan rasio PAD terhadap total pendapatan daerah dan rasio Dana Perimbangan terhadap total pendapatan daerah. Data APBD yang digunakan adalah total seluruh pendapatan daerah kabupaten dan kota se-Provinsi Banten yang terdiri dari total pendapatan yang berasal dari PAD, Dana Perimbangan, dan Lain-lain Pendapatan Daerah yang Sah. Peningkatan RPAD menunjukkan kemandirian keuangan daerah yang juga semakin meningkat namun peningkatan RDP mengindikasikan ketergantungan daerah pada sumber dana pemerintah pusat semakin tinggi.

Rasio PAD terhadap total pendapatan daerah dapat mengukur kemampuan keuangan daerah. Nilai interval yang minimal lebih besar dari $50 \%$ menunjukkan kemampuan keuangan daerah yang baik. Semakin besar rasio PAD terhadap total pendapatan daerah maka kemampuan keuangan daerah semakin baik. Badan Litbang Depdagri dan Fisipol UGM menggunakan skala interval yang dapat dilihat pada Tabel 3.

Tabel 3. Interval kemampuan keuangan daerah

\begin{tabular}{cc}
\hline Interval & Kemampuan Keuangan Daerah \\
\hline $00,00-10,00$ & Sangat Kurang \\
$10,01-20,00$ & Kurang \\
$20,01-30,00$ & Cukup \\
$30,01-40,00$ & Sedang \\
$40,01-50,00$ & Baik \\
$>50,00$ & Sangat Baik \\
\hline
\end{tabular}

Sumber: Depdagri dan Fisipol UGM (1991) 
Analisis regresi dengan metode panel data adalah metode yang menggunakan penggabungan data cross section dan time series dimana data yang dikumpulkan secara cross section pada periode waktu tertentu, dengan menggunakan tiga teknik untuk mengestimasi parameternya yang terdiri dari metode pooled least square, fixed effect dan random effect (Arief, 1993). Analisis panel data ini digunakan untuk mengidentifkasi pengaruh kemandirian keuangan daerah terhadap pertumbuhan ekonomi dan kemiskinan kabupaten dan kota di Provinsi Banten. Produk Domestik Regional Bruto (PDRB) adalah pendapatan total dan pengeluaran total daerah atas output barang dan jasa suatu daerah untuk menggambarkan pertumbuhan ekonomi. Variabel rasio PAD (RPAD) terhadap total pendapatan daerah dan variabel rasio Dana Perimbangan (RDP) terhadap total pendapatan daerah digunakan sebagai gambaran kemandirian keuangan daerah. Adapun estimasi model pengaruh kemandirian keuangan daerah terhadap pertumbuhan ekonomi kabupaten dan kota di Provinsi Banten dituliskan sebagai berikut:

$\operatorname{LnPDRB} B_{i t}=\alpha_{1}+\beta_{1} R P A D_{i t}+\beta_{2} R D P_{i t}$
$+\varepsilon_{i t}$

Keterangan:

PDRB $=$ Produk Domestik Regional Bruto (miliar rupiah)

RPAD $=$ Rasio PAD terhadap total pendapatan daerah (\%)

$\mathrm{RDP}=$ Rasio Dana Perimbangan terhadap total pendapatan daerah $(\%)$

$\alpha_{\mathrm{i}} \quad=$ intersep

$\beta \mathrm{i}=$ koefisien regresi

$\varepsilon_{\mathrm{it}} \quad=$ error term

$\mathrm{i} \quad=$ kabupaten/ kota ke-i

$\mathrm{t}=$ adalah periode waktu $(2001, \ldots, 2011)$

\section{HASIL DAN PEMBAHASAN \\ Perkembangan Kemandirian Keuangan Daerah}

Pendapatan Asli Daerah (PAD) bertujuan memberikan kewenangan kepada pemerintah daerah sebagai pendanaan pelaksanaan otonomi daerah sesuai dengan potensi daerah. Undangundang Nomor 33 Tahun 2004 pasal 6 menyebutkan PAD berasal dari empat sumber yaitu Pajak Daerah, Restribusi Daerah, Hasil Pengelolaan Kekayaan Daerah yang Dipisahkan dan Lain-lain Pendapatan Asli Yang Sah, Berdasarkan proporsi realisasi PAD, Pajak Daerah memberikan proporsi terbesar terhadap PAD. Selama kurun waktu tahun 20012011, proporsi pajak Provinsi Banten mencapai 96,11\%, sedangkan Restribusi Daerah, Hasil Pengelolaan Kekayaan Daerah yang Dipisahkan dan Lain-lain Pendapatan yang Sah masing-masing hanya sebesar $0,19 \%, 1,20 \%$ dan $2,50 \%$.

PAD merupakan sumber pembiayaan yang seluruhya digali dari daerah itu sendiri sehingga dapat mencerminkan kondisi riil daerah tersebut. Jika struktur PAD sudah kuat, artinya daerah tersebut memiliki kemampuan pembiayaan yang kuat, yang akhirnya berbagai bentuk dari pemerintah pusat hanya bersifat sebagai pendukung bagi pelaksanaan pemerintahan dan pembangunan di daerah. Rasio PAD terhadap total pendapatan daerah Provinsi Banten dapat dilihat dari Gambar 2. Berdasarkan Gambar 2, wilayah Banten Utara memiliki rasio PAD relatif lebih tinggi dibandingkan wilayah Banten Selatan. Kota Cilegon memiliki rasio PAD tertinggi namun Kabupaten Serang memiliki rasio PAD terendah di Banten Utara. Kemudian wilayah Banten Selatan yang terdiri dari Kabupaten Pandeglang dan Kabupaten Lebak memiliki rasio 
terendah dibandingkan wilayah Banten Utara.

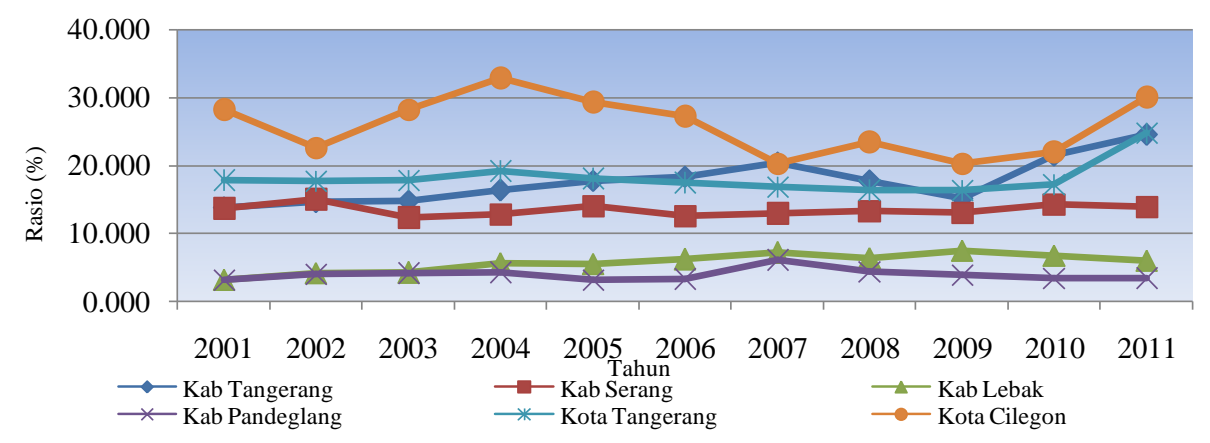

Sumber: DPKAD Banten, 2013 (diolah)

Gambar 2. Rasio pendapatan asli daerah terhadap total pendapatan daerah kabupaten dan kota di Provinsi Banten tahun 2001-2011

Pada tahun 2001, Kota Cilegon memiliki rasio sebesar $28 \%$, kemudian mengalami kenaikan sampai tahun 2004 dan sempat menurun pada tahun 2005 kemudian berfluktuasi dan akhirnya pada tahun 2011 meningkat menjadi 30\%. Kabupaten Serang memiliki rasio sebesar $13,63 \%$ pada tahun 2001 dan meningkat menjadi sebesar 13,9\% pada tahun 2011. Kabupaten Pandeglang memiliki rasio sebesar 3,3\% pada tahun 2001, sempat memiliki angka tertinggi pada tahun 2007 sebesar $6,25 \%$, kemudian berfluktuasi sampai mencapai angka 3,3\% pada tahun 2011. Kabupaten Lebak memiliki rasio sebesar 3,13\% yang meningkat menjadi $5,19 \%$ pada tahun 2011. Kabupaten dan kota yang memiliki rasio PAD terhadap total pendapatan daerah yang tinggi menunjukkan kabupaten dan kota tersebut berhasil meningkatkan pendapatan yang bersumber dari daerah masing-masing dan mengurangi ketergantungan terhadap dana pemerintah pusat.

Rasio PAD terhadap total pendapatan daerah Kabupaten Tangerang, Kabupaten Serang dan Kota Tangerang dengan rata-rata per tahunnya masingmasing sebesar $17,70 \%, 13,42 \%$ dan
$18,13 \%$ jika dilihat dari interval dapat disimpulkan bahwa kemampuan keuangan daerah Kabupaten Tangerang, Kabupaten Serang dan Kota Tangerang masih kurang. Rasio PAD terhadap total pendapatan daerah Kabupaten Pandeglang dan Kabupaten Lebak dengan rata-rata setiap tahunnya hanya sebesar $3,9 \%$ dan $5,6 \%$ menunjukkan kemampuan keuangan daerah Kabupaten Pandeglang dan Kabupaten Lebak masih sangat kurang karena berada di interval antara 0,0\%-10\%. Kota Cilegon dengan rasio PAD terhadap total pendapatan daerah terhadap pendapatan daerah ratarata pertahunnya sebesar 25,83\% menunjukkan kemampuan keuangan daerah yang cukup.

Kemampuan keuangan daerah yang berada pada interval sedang dapat dicapai jika rasio PAD terhadap pendapatan daerah mencapai angka minimal 30,01\%$40,00 \%$, kemampuan keuangan daerah baik jika rasio mencapai pada interval $40,01 \%-50,00 \%$ dan sangat baik jika rasio mencapai pada interval lebih besar dari 50\%. Tingkat kemandirian keuangan daerah yang relatif rendah dan menunjukkan kemampuan keuangan daerah kabupaten kota Provinsi Banten 
yang masih berada pada tingkat sangat kurang, kurang dan cukup menunjukkan bahwa ketergantungan fiskal pada pemerintah pusat masih tinggi.

Kekurangan kemampuan keuangan daerah dibantu dengan penerimaan yang berasal dari Dana Perimbangan. Hal ini didukung dengan rasio Dana Perimbangan terhadap total pendapatan daerah masing-masing kabupaten dan kota Provinsi Bante. Dana Perimbangan dana yang bersumber dari pendapatan APBN yang dialokasikan kepada daerah untuk mendanai kebutuhan daerah dalam rangka pelaksanaan desentralisasi.

Dana Perimbangan bertujuan mengurangi kesenjangan fiskal antara pemerintah pusat dan pemerintah daerah dan antar-pemerintah daerah. Undangundang Nomor 33 Tahun 2004 pasal 10 menyebutkan Dana Perimbangan berasal dari tiga sumber yaitu Dana Bagi Hasil, Dana Alokasi Umum dan Dana Alokasi Khusus. Berdasarkan proporsi realisasi Dana Perimbangan, Dana Bagi Hasil Pajak dan Bukan Pajak memberikan proporsi terbesar terhadap Dana Perimbangan sebesar $52,84 \%$ diikuti dengan Dana Alokasi Umum sebesar 45,94\%, sedangkan Dana Alokasi Khusus hanya menyumbang pendapatan sebesar 1,21\% selama kurun waktu 2001-2011.

Perkembangan rasio Dana Perimbangan terhadap total pendapatan daerah kabupaten dan kota Provinsi Banten disajikkan pada Gambar 3, Berdasarkan perkembangan setiap daerah, wilayah Banten memiliki rasio Dana Perimbangan terhadap total pendapatan daerah paling tinggi. Kabupaten Pandeglang memiliki rasio Dana Perimbangan tertinggi yaitu sebesar 93\% pada tahun 2001 dan mengalami fluktuasi serta menurun menjadi $82 \%$ pada tahun 2011, diikuti oleh Kabupaten Lebak pada posisi kedua tertinggi yaitu mencapai 93\% pada tahun 2001 dan menurun menjadi 76\% pada tahun 2011. Pada wilayah Banten Utara, Kota Cilegon memiliki rasio paling rendah yaitu sebesar $63 \%$ pada tahun 2001 dan menurun menjadi 52\% pada tahun 2011, sedangkan Kabupaten Serang memiliki rasio paling tinggi yaitu sebesar $84 \%$ pada tahun 2001 dan menurun menjadi sebesar $60 \%$ pada tahun 2011.

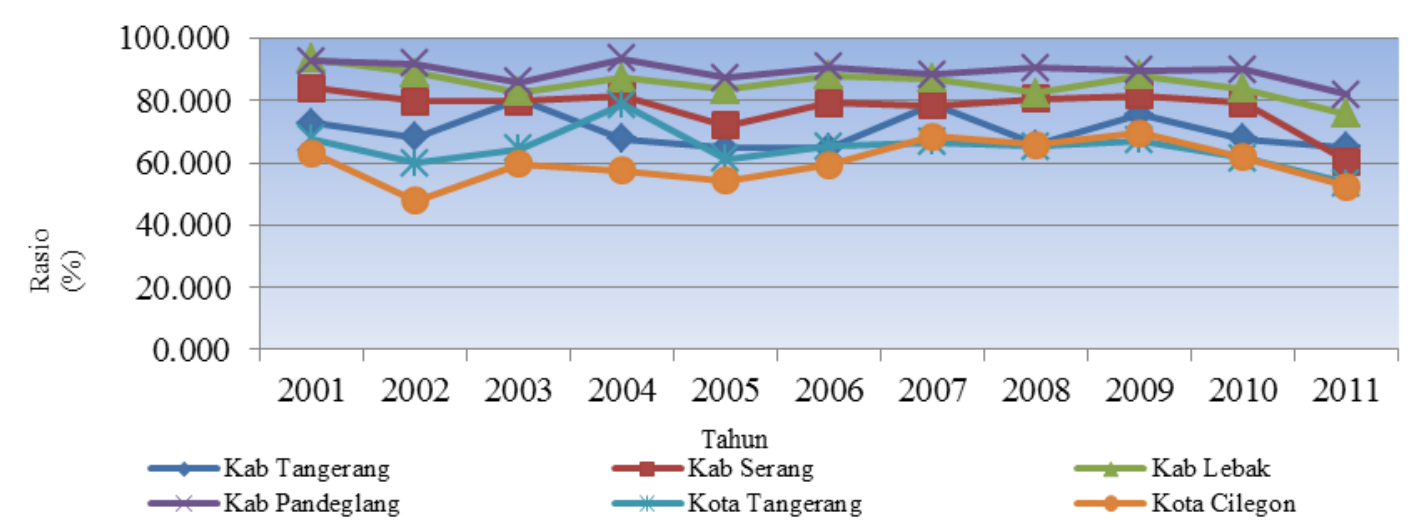

Sumber: DPKKD Banten, 2013 (diolah)

Gambar 3. Rasio Dana Perimbangan terhadap total pendapatan daerah kabupaten dan kota di Provinsi Banten tahun 2001-2011

Daerah dengan rasio Dana Perimbangan yang rendah menunjukkan daerah tersebut memiliki ketergantungan yang rendah terhadap dana pihak luar, sebaliknya rasio Dana Perimbangan yang tinggi menunjukkan daerah tersebut memiliki ketergantungan yang tinggi terhadap bantuan dana pemerintah pusat. 
Meskipun perkembangan pendapatan yang berasal dari PAD semakin meningkat, namun perbandingan RPAD dengan RDP menunjukkan Dana Perimbangan memberikan kontribusi yang relatif lebih tinggi dibandingkan dengan dengan PAD. Hal ini mengindikasikan, pada masing-masing kabupaten dan kota di Provinsi Banten, penggunaaan dana bantuan pemerintah pusat masih berperan lebih besar pada anggaran pendapatan daripada Pendapatan Asli Daerah, dan kemandirian keuangan pada masingmasing kabupaten dan kota masih rendah.

\section{Pengaruh Kemandirian Keuangan Daerah terhadap Pertumbuhan Ekonomi}

Estimasi model diperoleh dengan menggunakan metode panel data. Hasil uji Chow dan uji Hausman yang dapat dilihat pada Lampiran 1 dan 2, menunjukkan model dengan pendekatan Fixed Effect merupakan model yang terbaik. Masing-masing variabel bebas menunjukan nilai probabilitas yang signifikan sehingga model penduga sudah layak untuk menduga parameter yang ada di dalam fungsi. Pengujian model menunjukkan bahwa model terbebas multikolineritas, autokorelasi dan heteroskedastisitas serta didasarkan pada asumsi bahwa faktor kesalahan $u_{i}$ menyebar secara normal.

Hasil estimasi menunjukkan pengaruh yang positif secara signifikan dari RPAD terhadap pertumbuhan ekonomi di Provinsi Banten. Hal ini menunjukkan bahwa semakin tinggi tingkat kemandirian keuangan daerah akan berimplikasi pada kenaikan pertumban ekonomi. Kenaikan $1 \%$ rasio PAD terhadap total pendapatan daerah akan meningkatkan pertumbuhan ekonomi sebesar 0,283001\%, dengan asumsi ceteris paribus. Hal ini sesuai dengan teori umum yang digunakan untuk melihat hubungan antara desentralisasi fiskal dengan pertumbuhan ekonomi bahwa pada sistem desentralisasi fiskal dimana pemerintah daerah memainkan peran yang lebih penting daripada pemerintah pusat dalam penyediaan pelayanan publik akan mendorong pertumbuhan ekonomi Tiebout (1961).

Hasil estimasi menunjukkan variabel rasio Dana Perimbangan terhadap total pendapatan daerah secara signifikan negatif mempengaruhi pertumbuhan ekonomi. Kenaikan 1\% rasio Dana Perimbangan terhadap total pendapatan daerah akan menurunkan pertumbuhan ekonomi sebesar 0,362936\%, dengan asumsi ceteris paribus. Tingginya ketergantungan keuangan daerah terhadap transfer dana pemerintah pusat mengindikasikan kemandirian keuangan daerah yang menurun, sehingga akan mengurangi kinerja pemerintah daerah dalam meningkatkan output perekonomian. Penerimaan dana yang tinggi dari pemerintah pusat dapat menyebabkan pemerintah daerah kurang insentif untuk meningkatkan pemerimaan yang berasal dari PAD dan terus mengandalkan kemampuan negosiasi untuk menerima bantuan dari pihak luar sebagai pembiayaan pemerintahan dan pembangunan. Hasil estimasi menunjukkan bahwa Kota Tangerang memiliki rata-rata perubahan PDRB terbesar di Provinsi Banten, sedangkan Kabupaten Lebak memiliki rata-rata perubahan PDRB terkecil di Provinsi Banten. 
Tabel 4. Hasil estimasi model pengaruh kemandirian keuangan daerah terhadap pertumbuhan ekonomi kabupaten dan kota di Provinsi Banten tahun 20012011

\begin{tabular}{ccccc}
\hline \multicolumn{1}{c}{ Variabel } & Koefisien & Std, Error & t-Statistic & Prob, \\
\hline C & 16,17459 & 0,081426 & 198,6425 & 0,0000 \\
RPAD & 0,283001 & 0,135281 & 2,091946 & 0,0408 \\
RDP & $-0,362936$ & 0,085572 & $-4,241315$ & 0,0001 \\
\hline R-squared & Weighted Statistics & Unweighted Statistics \\
Sum squared resid & 0,998936 & 0,940941 \\
Durbin-Watson stat & 54,61216 & 2,117066 \\
Prob(F-statistic) & 1,400121 & 0,209465 \\
\hline \multicolumn{2}{c}{ CROSSID } & 0,000000 & & \\
\hline Kab Tangerang & & Effect \\
Kab Serang & & 0,619132 \\
Kab Lebak & & $-0,136626$ & \\
Kab Pandeglang & & $-0,823225$ & \\
Kota Tangerang & & $-0,785138$ & \\
Kota Cilegon & & 0,962116 & \\
\hline
\end{tabular}

Sumber: Hasil pengolahan menggunakan program Eviews6

Keterangan: *) signifikan pada taraf 5\%

\section{SIMPULAN DAN SARAN}

\section{Simpulan}

Berdasarkan hasil dan pembahasan, maka dapat disimpulkan bahwa perkembangan kemandirian keuangan daerah selama kurun waktu tahun 20012011 kabupaten dan kota di Provinsi Banten semakin membaik namun penerimaan yang berasal dari Dana Perimbangan masih lebih tinggi daripada Pendapatan Asli Daerah (PAD).

Kemampuan keuangan daerah kabupaten dan kota Provinsi Banten masih berada pada interval cukup untuk Kota Cilegon. Kota Cilegon mempunyai rasio penerimaan PAD tertinggi sedangkan Kabupaten Tangerang, Kabupaten Serang dan Kota Tangerang mempunyai kemampuan keuangan yang kurang serta Kabupaten Pandeglang dan Kabupaten Lebak mempunyai kemampuan keuangan yang sangat kurang.
Kemampuan keuangan yang relatif kurang inilah yang menyebabkan kemandirian keuangan kabupaten dan kota Provinsi Banten relatif masih rendah. Wilayah Banten Selatan yang terdiri dari Kabupaten Pandeglang dan Kabupaten Lebak menerima pendapatan rasio PAD yang terendah serta rasio Dana Perimbangan yang tertinggi sehingga untuk menjadikan pemerintahan Kabupaten Pandeglang dan Kebupaten Lebak yang mampu mengurus rumah tangga dengan kemampuan sendiri, sulit diwujudkan karena tidak mungkin membiayai penyelenggaraan pemerintah dengan PAD yang minim.

Kemandirian keuangan daerah mempunyai pengaruh positif secara signifikan terhadap peningkatan pertumbuhan ekonomi di Provinsi Banten. Hasil penelitian menunjukkan rasio PAD berpengaruh positif secara signifikan pada pertumbuhan ekonomi. Ketergantungan terhadap Dana 
Perimbangan akan berpengaruh terhadap penurunan perekonomian.

\section{Saran}

Berdasarkan hasil dan pembahasan serta simpulan, maka dapat dirumuskan saran yaitu perlunya dilakukan evaluasi kebijakan alokasi penggunaan Dana Perimbangan. Perkembangan wilayah Banten Utara yang berhasil meningkatkan pendapatan yang berasal dari PAD lebih tinggi daripada Banten Selatan harus dipertahankan oleh pemerintah.

Peningkatan penerimaan PAD dapat dilakukan dengan meningkatkan pendapatan pajak karena pajak daerah sebagai penerimaan yang paling dominan untuk penerimaan PAD dan melakukan kebijakan yang memberikan kemudahan kepada masyarakat untuk melakukan aktivitas perekonomian khususnya pada bidang jasa, hotel dan restauran serta industri pengolahan dan juga pertanian karena sektor-sektor tersebut memiliki nilai yang paling tinggi terhadap peningkatan PDRB di Provinsi Banten Provinsi Banten.

Peningkatan pertumbuhan ekonomi dapat didukung dengan peningkatan kemandirian keuangan daerah khususnya pada daerah memiliki rata-rata perubahan PDRB terbesar di Provinsi Banten yaitu Kota Tangerang dan Kabupaten. Pengurangan ketergantungan Dana Perimbangan harus dilakukan dengan kebijakan yang tepat agar tidak mengganggu kinerja pemerintah dan ekonomi dalam jangka panjang serta penggunaannya sesuai dengan tujuan awal yaitu mengurangi kesenjangan keuangan antar daerah dan bersifat sebagai pendukung untuk tujuan pembangunan.

\section{DAFTAR PUSTAKA}

Akai, N dan Sakata M. 2002. Fiscal Decentralization Contributes To Economic Growth: Evidence From State-Level Cross-Section Data for The United States. Journal of Urban Economics. 52(2002): 93108.

Anonim. 2013. Dasar Hukum Jenis Pajak Daerah Dan Restribusi. www. www.djpk.depkeu.go. id/document. php/document/article/108/73/.

Diakses tanggal 14 Februari 2013.

Arief, S. 1993. Metodologi Penelitian Ekonomi. Penerbit Universitas Indonesia (UI- Press). Jakarta

[BPPD] Badan Perencanaan Pembangunan Daerah. 2012. Rancangan Awal Rencana Pembangunan Jangka Menengah Daerah Provinsi Banten Tahun 2012-2017. Serang (ID): BPPD.

[BPS] Badan Pusat Statistik. 2013. Provinsi Banten dalam Angka Berbagai Edisi. Serang (ID): BPS.

[BPS]. Badan Pusat Statistik. 2008. Analisis dan Penghitungan Tingkat Kemiskinan 2008, katalog BPS: 3205015. Jakarta (ID): BPS

Dartanto, T dan Brodjonegoro B. 2003. Dampak Desentralisasi Fiskal di Indonesia Terhadap Pertumbuhan Ekonomi dan Disparitas Antar Daerah: Analisa Model Makro Ekonometrik Simultan. Jurnal Ekonomi dan Pembangunan Indonesia. 4(1): 17-38.

Davoodi, H dan Zou H. 1998. Fiscal decentralization and economic growth: a cross-country study. Journal of Urban Economics. 43(2):244-245.

Enceng, Liestyodo, BI dan Purwaningdyah, MW. Desentralisasi Fiskal Penerimaan Keuangan Daerah. J Ilmu Administrasi Negara. 12(1):1-73. 
Mankiw, NG. 2007. Makroekonomi Edisi Keenam. Penerbit Erlangga. Jakarta

Oates, WE. 1999. An Essay on Fiscal Federalism. Journal of Economic Literature. 1999(37): 1120-1149

[RI]. Republik Indonesia. 1999. UndangUndang Republik Indonesia Nomor 22 Tahun 1999 tentang Pemerintahan Daerah. Jakarta (ID): RI

[RI]. Republik Indonesia. 1999. UndangUndang Republik Indonesia Nomor 25 Tahun 1999 tentang Perimbangan Keuangan Pemerintah Pusat dan Daerah. Jakarta (ID): RI

[RI]. Republik Indonesia. 2004. UndangUndang Republik Indonesia Nomor 32 Tahun 2004 tentang Pemerintahan Daerah. Jakarta (ID): RI

[RI]. Republik Indonesia. 2004. UndangUndang Republik Indonesia Nomor 33 Tahun 2004 tentang Perimbangan Keuangan Pemerintah Pusat dan Daerah. Jakarta (ID): RI.

Samimi AJ, Lar SKP, Haddad GK, Alizadeh M. 2010. Fiscal Decentralization and Economic Growth in Iran. Australian Journal of Basic and Applied Sciences. 4(11): 5490-5495.

Tibeout, CM. 1961. An Economic Theory of Fiscal Decentralization. National Bureau of Economiz Research. 1961: 79-96

Todaro, P dan Smith SC. 2006. Pembangunan Ekonomi edisi kesembilan. Penerbit Erlangga. Jakarta

Zhang T dan Zou HF. 1996. Fiscal Decentralization, Public Spending And Economic Growth in China. Policy Research Working Paper. 1608 
Lampiran 1. Hasil Uji Chow

\section{LAMPIRAN}

Redundant Fixed Effects Tests

Equation: Untitled

Test cross-section fixed effects

\begin{tabular}{lccr}
\hline \hline Effects Test & Statistic & d.f. & Prob. \\
\hline \hline Cross-section F & 1658.079192 & $(5,58)$ & 0.0000 \\
\hline \hline
\end{tabular}

Lampiran 2. Hasil Uji Hausman

Correlated Random Effects - Hausman Test

Equation: Untitled

Test cross-section random effects

\begin{tabular}{lrrr}
\hline \hline Test Summary & Chi-Sq. Statistic & Chi-Sq. d.f. & Prob. \\
\hline \hline Cross-section random & 9.809037 & 2 & 0.0074 \\
\hline \hline
\end{tabular}

